\title{
EFEKTIVITAS PEMBERIAN SARI KURMA DAN MADU DALAM MENINGKATKAN KADAR HEMOGLOBIN PADA IBU HAMIL ANEMIA
}

\author{
Alfiah Rahmawati $^{1}$, Arum Meiranny ${ }^{2}$,Eka Dewi Setianing Tiyas ${ }^{3}$ \\ Program Sarjana Bidan Fakultas Kedokteran Universitas Islam Sultan Agung ${ }^{123}$ \\ Email: '1alfiahrahmawati@Unissula.Ac.Id, ${ }^{2}$ Arummeiranny@Unissula.Ac.Id, \\ ${ }^{3}$ Ekadewi296@Gmail.Com
}

\begin{abstract}
Introduction: Anemia is the biggest public health problem in the world, especially for women of reproductive age (WUS). The benefits of dates for health include anti-diabetes, anti-microbial, anti-inflammatory, anti-oxidant, antihyperlipidemic, preventing anemia, rickets, and osteomalacia, as well as facilitating labor in laboring mothers. The iron content in honey is a very important microminerary needed in the body. Apart from that, another content of honey which plays an important role in dissolving iron is vitamin C.Methods: National and international literature was traced through several media using keywords as the PICO formula.The articles that were reviewed were 6 articles. Result: the administration of date palm juice and honey is very effective in increasing hemoglobin levels in anemic pregnant women. The administration of date palm juice and honey can help increase hemoglobin levels, because of the high iron content in dates. Conclusion: date palm juice and honey can increase hemoglobin levels in anemic pregnant women.
\end{abstract}

Key words: anemia, hemoglobin, dates, palm juice, honey.

\begin{abstract}
ABSTRAK
Pendahuluan : Anemia merupakan masalah kesehatan masyarakat terbesar di dunia terutama bagi kelompok wanita usia reproduksi (WUS). Manfaat kurma bagi kesehatan antara lain adalah sebagai anti diabetes, anti mikroba, anti inflamasi, anti oksidan, anti hiperlipidemik, mencegah anemia, rakhitis, dan osteomalasia, serta memperlancar persalinan pada ibu bersalin. Kandungan zat besi di dalam madu merupakan mikromineral yang sangat penting dibutuhkan dalam tubuh. Selain itu kandungan lain madu yang berperan penting dalam melarutkan zat besi yaitu vitamin C. Metode : Literatur nasional dan internasional ditelusuri melalui beberapa media menggunakan kata kunci sebagaimana rumus PICO. Artiker yang ditelaah sebanyak 6 artikel .Hasil : pemberian sari kurma dan madu sangat efektif dalam meningkatkan kadar hemoglobin pada ibu hamil anemia pembahasan : pemberian sari kurma dan madu dapat membantu meningkatakan kadar hemoglobin, karena adanya kandungan zat besi yang tinggi dalam kurma. kesimpulan :sari kurma dan madu dapat meningkatkan kadar hemoglobin pada ibu hamil anemia.
\end{abstract}

Kata kunci : anemia, hemoglobin, kurma, sari kurma, madu. 


\section{Vol. 16 No.2 Mei - Agustus 2021}

\section{PENDAHULUAN}

Anemia merupakan kondisi atau keadaan ditandai dengan adanya penurunan kadar hemoglobin $(\mathrm{Hb})$, hematokrit atau jumlah sel darah merah. Kadar $\mathrm{Hb}$ dan sel darah bervariasi tergantung pada usia, jenis kelamin, ketinggian suatu tempat, serta keadaan fisiologi tertentu (Sudoyo, 2013). Menurut Depkes (2009) anemia dalam kehamilan adalah kondisi dimana ibu hamil dengan kadar hemoglobin dibawah 11 gr\% pada trimester I dan III atau <10,5 gr\% pada trimester II. Anemia sering dijumpai dalam kehamilan karena dalam kehamilan kebutuhan zat-zat makanan ibu hamil mengalami perrtambahan dan terjadi perubahan perubahan dalam darah dan sumsum tulang sehingga seringkali ibu mengalami anemia (Prawirohardho, 2014).

Penyeba tingginya prevalensi anemia pada ibu hamil salah satunya yaitu kebutuhan zat besi yang meningkat akibat perubahan fisiologi dan metabolisme pada ibu hamil, inadequate intake (utamanya zat besi, dan juga defisiensi asam folat dan vitamin B12), gangguan penyerapan, infeksi (malaria dan kecacingan), kehamilan yang berulang, thalasemia dan sickle cell disease, kondisi sosial, ekonomi, budaya dan pendidikan ibu yang juga mempengaruhi (Hidah, 2009).

Rendahnya kemampuan fisik ibu karena selsel tubuh tidak cukup mendapat pasokan oksigen dapat mengakibatkan anemia pada ibu hamil. Hal ini secara umum dikarenakan, pengkonsumsian zat besi masih belum bisa memenuhi kebutuhan tubuh apabila jumlah oksigen dalam tubuh berkurang sehingga akan mengganggu sistem kinerja organ yang bersangkutan menurun dan terganggu. Ada beberapa risiko apabila terjadi anemia pada ibu dan janin adalah berat badan lahir rendah, perdarahan antepartum, infeksi, odema pulmo, Intra Uterine Growyh Retardation (IUGR), kecacatan, kelainan kongenital, bahkan kematian

Haemoglobin adalah molekul protein yang mengangkut sel darah merah sebagai media transportasi O2, Haemoglobin dibentuk dalam sel darah merah pada sumsum tulang belakang,dan kegagalan pembentukan haemoglobin dapat disebabkan karena kekurangan protein. Faktor pembentuk hemoglobin yaitu $\mathrm{Fe}$, B12 dan, asam folat semuanya terdapat dalam kurma. Kurma memiliki berbagai macam kandungan nutrisi sebagai berikut: kaliumasam salisilat, gula, vitamin A, 
thiamin, riboflavin, niasin, karatenoid, fosfor, serat pangan, lemak tak jenuh, serta zat besi.

Kurma yang dalam Bahasa Latin disebut Phoenix dactylifera adalah buah yang tumbuh khas di daerah gurun pasir. Buah ini telah lama dikenal dan merupakan salah satu buah yang paling penting di wilayah Arab, Afrika Utara, dan Timur Tengah. Kurma mengandung Riboflavin, Niasin, Piridoksal, dan Folat dimana dalam 100 gram kurma memenuhi lebih dari 9\% kebutuhan vitamin sehari. Kurma matang kaya akan kandungan kalsium dan besi. Kandungan besi yang ada di dalam buah kurma yaitu 1,02 mg. Berbagai hasil penelitian seperti (Febriansyah, 2007), (Onuh, 2012) dan (Pravitasari, 2014) menunjukkan hasil yang nyata kenaikan serum Fe setelah pemberian kurma.

Manfaat kurma bagi kesehatan antara lain adalah sebagai anti diabetes, anti mikroba, anti inflamasi, anti oksidan, anti hiperlipidemik, mencegah anemia, rakhitis, dan osteomalasia, serta memperlancar persalinan pada ibu bersalin. (Munafiah, Kusyati, \& Inayati, 2019) Untuk mengatasai anemia dapat dilakukan beberapa pencegahan dan penanganan yaitu dengan meminum tablet tambah darah $(\mathrm{Fe})$ yang sudah dianjurkan oleh tenaga kesehatan. Selain itu meningkatkan konsumsi makanan yang mengandung zat besi baik dari sumber makanan hewani maupun dari sumber makanan nabati. Vitamin C (asam askorbat) berkontribusi besar proses absorpsi zat besi. Vitamin C dapat diperoleh dari tablet suplemen vitamin $\mathrm{C}$ maupun dari buah- buahan dan sayuran.

Kandungan zat besi di dalam madu merupakan mikromineral yang sangat penting dibutuhkan dalam tubuh. Selain itu kandungan lain madu yang berperan penting dalam melarutkan zat besi yaitu vitamin C. Madu juga mengandung beberapa multi mineral yang yaitu: belerang (S), kalsium $(\mathrm{Ca})$, tembaga $(\mathrm{Cu})$, mangan $(\mathrm{Mn})$, besi $(\mathrm{Fe})$, fosfor $(\mathrm{P})$, klor $(\mathrm{Cl})$, kalium $(\mathrm{K})$, magnesium $(\mathrm{Mg})$, iodium (I), seng $(\mathrm{Zn})$, silikon $(\mathrm{Si})$, natrium $(\mathrm{Na})$, molibdenum (Mo) dan aluminium (Al) sedangkan potasium merupakan mineral utama pada madu, Selain itu madu mengandung multivitamin yang meliputi vitamin $\mathrm{E}$, vitamin $\mathrm{C}$ serta vitamin $\mathrm{B} 1, \mathrm{~B} 6$, dan asam folat.(Isnainy, Arianti, \& Rosalia, 2020). 


\section{Vol. 16 No.2 Mei - Agustus 2021}

\section{METODE}

Peneliti melakukan pencarian artikel melalui berbagai media elektronik atau pun database diantaranya google scholar, PMC,

DOAJ. Dilakukannya artikel ini bertujuan untuk mengupas efektifitas pemberian sari kurma dan madu dalam meningkatakan kadar hemoglobin pada ibu hamil yang mengalami anemia. Dalam membuat literature ini Kata kunci yang digunakan dalam yaitu “anemia,hemoglobin, sari kurma, kurma, madu”. Dan setelah dilakukan pencarian didapatkan beberapa jurnal nasional dan internasional yang dapat mendukung sebagai acuan sumber literature ini.

Penelitian yang dilakukan pada tahun 2017 dengan judul "Efektivitas Penambahan Sari Kurma Dalam Pemenuhan Gizi Ibu Hamil Anemia Di Puskesmas Wedi, Kabupaten Klaten” Penyebab yang sering anemia selama kehamilan yaitu defisiensi besi dan kehilangan darah akut. keduanya saling berkaita, karena pengeluaran darah yang berlebihan disertai hilangnya besi hemoglobin dan terkurasnya simpanan besi pada ibu hamil dapat menjadi penyebab penting anemia defisiensi besi pada kehamilan berikutnya. Status gizi yang kurang sering berkaitan dengan anemia defisiensi besi. Berdasarkan hasil penelitian didapatkan kesimpulan sebagai berikut 1. Kadar hemoglobin ibu hamil anemia yang diberi MMN ratarata adalah 10,4 mmHg 2. Kadar hemoglobin ibu hamil anemia yang sebelum diberi sarikurma rata-rata 10,38 dan sesudah diberi sarikurma rata-rata 10,84 . 3. Sarikurma lebih efektif dibandingkan dengan $\mathrm{MMN}$ dengan nilai $\mathrm{p}=$ $0,045(\mathrm{p}<0,05)$.

$$
\text { Penelitian dengan judul "Pengaruh }
$$
Pemberian Sari Kurma Terhadap Peningkatan Kadar Hemoglobin Ibu Hami" Hasil penelitian didapatkan kadar hemoglobin responden sebelum konsumsi sari kurma terendah yaitu $8,1 \mathrm{gr} / \mathrm{dL}$ dan yang tertinggi yaitu 10,4 gr/dL, rata-rata sebesar $9,6 \mathrm{gr} / \mathrm{dL}$. Responden yang mengalami anemia banyak terjadi pada umur ibu tidak berisiko yaitu umur 20-35 tahun sebanyak 10 responden. Pada penelitian ini, jumlah responden lebih dari 90\% ibu yang berusia 20-35 tahun. Hasil penelitian ini menunjukkan bahwa usia tidak beresiko kehamilan tetap mempunyai peluang untuk tetap mengalami anemia. Hasil penelitian didapatkan hasil bahwa setelah konsumsi sari kurma sebanyak $10(90,9 \%)$ mengalami peningkatandan $1(9,1 \%)$ yang mengalami penurunan kadar hemoglobin. Pravitasari menyatakan bahwa ekstrak buah kurma dapat meningkatkan kadar hemoglobin . Zat besi yang tinggi dapat digunakan untuk pengobatan anemia. Anemia adalah keadaan jumlah sel darah merah atau jumlah hemoglobin (protein pembawa oksigen) 
dalam sel darah merah berada di bawah normal. Zat besi dalam kurma nantinya diserap oleh usus dan dibawa oleh darah untuk hemopoiesis (proses pembentukan darah) .

Pada jurnal yang berjudul "Pengaruh Konsumsi Buah Kurma Terhadap Peningkatan Kadar Hemoglobin Pada Ibu Hamil Trimester III" Berdasarkan hasil analisis univariat Rerata kadar hemoglobin sebelum konsumsi kurma yaitu 10,793 gr/dl dan rerata kadar haemoglobin sesudah konsumsi kurma yaitu 11,933 gr/dl. Dapat dilihat bahwa terdapat peningkatan dari rata rata dari sebelum dan sesudah pada kelompok perlakuan. Hasil penelitian ini sama dengan penelitian yang dilakukan oleh Sendra, E (2016) bahwa adanya peningkatan kadar $\mathrm{Hb}$ pada ibu hamil sebanyak $60 \%$ responden. Peningkatan kadar $\mathrm{Hb}$ dimungkinkan karena nutrisi yang adekuat ditambah dengan konsumsi kurma 25 gram/hari selama 30 hari serta konsumsi tablet Fe. terlihat bahwa rata-rata kadar hemoglobin pada kelompok perlakuan kadar hemoglobin pre (sebelum) pemberian kurma sebesar 10,793 dan post (setelah) pemberian kurma terjadi peningkatan sebesar 11,933 sehingga terlihat perbedaan dari nilai rata- rata pre dan post sebesar 1,140 dengan standar deviation 0,6643. Hasil uji statistik didapatkan nilai $\mathrm{p}$ value $<0,05(0,002<0,05)$ sehingga Ho ditolak, Ha diterima yang dapat disimpulkan, terdapat perbedaan kadar hemoglobin yang bermakna antara sebelum dan sesudah (pre test dan post test). Hal ini menjelaskan bahwa adanya pengaruh konsumsi buah kurma terhadap peningkatan kadar hemoglobin ibu hamil trimester III di wilayah kerja Puskesmas Klateng.

Pada penelitian yang berjudul "Pengaruh Pemberian Madu Terhadap Kadar Hb Pada Ibu Hamil Trimester Iii Di Uptd Puskesmas Peniangan Kecamatan Marga Sekampung Kabupaten Lampung Timur" Jenis penelitian ini merupakan jenis penelitian kuantitatif. rancangan penelitian pra eksperimen yang menggunakan jenis One Group Pretest-Postest. Populasi dalam penelitian ini adalah seluruh ibu hamil trimester III awal (29 minggu) sebanyak 362 ibu hamil. Madu dapat mempengaruhi peningkatan kadar hemoglobin remaja yang mengalami anemia. Madu mengandung asam folat, vitamin B1, kalium, vitamin A, vitamin $\mathrm{C}$, kalsium, dan zat besi. Kandungan yang terdapat dalam madu bermanfaat sebagai anti anemia atau dapat meningkatan kadar hemoglobin dalam darah. Madu lebih mudah diserap daripada daging atau bahan lainnya, madu dapat dikonsumsi 3 kali dalam seminggu untuk remaja dapat 


\section{Vol. 16 No.2 Mei - Agustus 2021}

memberikan pengaruh terhadap peningkatan kadar hemogobin remaja (Fatimah St, 2011). Pada hasil penelitian di dapatkan hasil peningkatan kadar $\mathrm{Hb}$ yang beragam pada setiap responden, dimulai dari peningkatan terendah yaitu 0,2 gr\% hingga tertinggi 1,8 gr\% kadar haemoglobin setetelah intervensi , hal ini dikarenakan responden mengikuti dengan baik atau tidak hal yang dianjurkan oleh peneliti mereka rutin meminum madu hutan selama 14 hari untuk membantu menaikan kadar Hb.

Pada jurnal penelitian tahun 2020 yang berjudul "Pengaruh Konsumsi Sari Buah Jambu Merah dan Madu terhadap Kenaikan Nilai HB pada Ibu Hamil di Tempat Praktek Mandiri Bidan Muarofah Surabaya" Berdasarkan hasil penelitian menunjukkan bahwa setelah diberikan sari buah psidium guajava dan madu pada kelompok perlakuan sebagian besar nilai $\mathrm{Hb}$ meningkat rata-rata $10,25 \mathrm{gr} \%$. Sedangkan pada kelompok kontrol tidak terdapat perbedaan sebelum dan setelah diberikan perlakuan yaitu hb rata-rata 9,81gr\%. Peningkatan nilai $\mathrm{Hb}$ setelah diberikan intervensi karena didalam Psidium guajava mengandung zatbesi sebesar 1,1mg,dimana zat gizi $1,1 \mathrm{mg}$ tersebut berperan dalam pembentukan sel darah merah. Fungsi vitamin $\mathrm{C}$ yang terkandung dalam jambu biji merah adalah menyusutkan besi feri $(\mathrm{Fe} 3+)$ menjadi ferro $(\mathrm{Fe} 2+)$ di dalam usus halus sehingga mudah diabsorpsi.(Isnainy, 2020). Berdasarkan hasil analisis data menggunakan uji wilcoxon didapatkan hasil pada kelompok perlakuan nilai $\mathrm{p}=0,000$ (P0,05),yang artinya terdapat perbedaan nilai perbandingan pre test dan post test pada kelompok perlakuan dan kontrol. sedangkan perbandingan antara kelompok perlakuan dan kontrol menggunakan uji chi square di dapatkan hasil $\mathrm{p}=0,000(\mathrm{p}=0,000(\mathrm{p}<0,05$

) yang artinya terdapat pengaruh yang pemberian sari buah psidium guajava dan madu terhadap peningkatan nilai $\mathrm{Hb}$ wanita hamil yang mengalami anemia ringan.

\section{HASIL DAN PEMBAHASAN}

Dari hasil literatur riview yang telah dipaparkan semua artikel menjabarkan bebrapa hasil penelitian tentang pemberian sari kurma dan madu untuk meningkatkan kadar hemoglobin pada ibu hamil anemia, namun ada satu jurnal yang mengatakan bahwa tidak ada pengaruh kenaikan hemoglobin yang mengkonsumsi sari kurma dan jurnal lainnya mengatakan ada pengaruh mengkonsumsi buah kurma maupun ekstrak kurma yang dicampur dengan madu dapat meningkatkan kadar hemoglobin ibu hamil anemia. Rata-rata hemoglobin ibu hamil 
sebelum diberikan kurma yaitu anemia ringan, namun setelah di berikan buah kurma atau sari kurma dan madu hemoglobin mengalami peningkatan. Sari Kurma dan madu dapat dikategorikan sebagai salah satu alternative yang dapat dipilih dalam memenuhi kebutuhan zat besi selama masa kehamilan, asalkan mengkonsumsi secara rutin agar hemoglobin mengalami peningkatan . Berdasarkan teori dijelaskan bahwa asam folat yang terkandung di dalam buah kurma dan madu dapat meningkatkan leukosit dan trombosit dalam batas normal .

\section{KESIMPULAN DAN SARAN}

\section{Simpulan}

Berdasarkan analisa yang telah dilakukan pada beberapa jurnal dan artikel dapat disimpulkan bahwa pemberian sari kurma dan madu dapat meningkatakan kadar hemoglobin pada ibu hamil anemia .

\section{Saran}

1. Bagi institusi pendidikan Hasil penelitian ini dapat digunakan sebagai masukan untuk menambah wawasan khususnya tentang kurma dan madu terhadap ibu hamil Anemia

2. Bagi penulis
Dapat mengaplikasikan ilmu yang diperoleh dengan memberikan informasi kepada ibu hamil tentang kurma dan madu untuk peningkatan kadar Hemoglobin.

3. Bagi profesi Bidan

Sebagai salah satu upaya promotif dan preventif bagi bidan dalam menangani masalah peningkatan hemoglobin ibu hamil.

4. Bagi ibu hamil

Dapat melakukan penanganan pada anemia dengan cara yang lebih alami yaitu dengan konsumsi kurma sehingga meningkatkan kadar Hemoglobin, serta lebih ekonomis dan praktis.

5. Bagi pelayanan kesehatan Menambah pengalaman bagi pelayanan dalam memberikan metode peningkatan kadarhemoglobin ibu hamil

\section{DAFTAR PUSTAKA}

1. Inayah. Unnes Journal of Life Science Efek Madu Randu dan Kelengkeng dalam Menurunkan Kolesterol pada Tikus Putih Hiperkolesterolemik Inayah , Aditya Marianti , Lisdiana Info Artikel Abstrak Abstra ct. 2012;1(1):5. 


\section{Vol. 16 No.2 Mei - Agustus 2021}

2. Citra E, Sampurno, Andayani N, Ratih D.

Pengaruh Promosi Above the Line dan

Kesadaran Merk terhadap Keputusan

Pembelian Produk Madu TJ. Heal Tadulako J

(Jurnal Kesehat Tadulako) [Internet].

2019;5(3):55-63. Available from:

http://jurnal.untad.ac.id/jurnal/index.p

hp/HealthyTadulako/article/download

$/ 15369 / 11428$

3. Apriyanti F. Hubungan Status Gizi Dengan

Kejadian Anemia Pada Remaja Putri Sman

1 Pangkalan Kerinci Kabupaten Pelalawan

Tahun 2019. J Doppler Univ Pahlawan

Tuanku Tambusai. 2019;3(2):18-21.

4. Suhariyati S, Rahmawati A, Realita F.

Hubungan antara Pola Menstruasi dengan

Kejadian Anemia pada Mahasiswi Prodi

Sarjana Kebidanan Unissula Semarang. J

Akad Baiturrahim Jambi. 2020;9(2):195.

5. Wulandari RCL, Susiloningtyas I. Betroot

(Beta vulgaris) administration to anemic

pregnant women for increasing hemoglobin

level. Maj Obstet Ginekol. 2020;28(3):109.

6. Rahmawati A, Silviana Y. Pengaruh

Konsumsi Kurma (Phoenix
Dactylifera) terhadap Kenaikan Kadar

Hemoglobin: A Review. J Kebidanan.

2019;9(1):97-102.

7. Hemoglobin K, Remaja P. PENTINGNYA SUPLEMEN TABLET BESI BAGI

PENINGKATAN KADAR

HEMOGLOBIN PADA REMAJA PUTRI

Rr. Catur Leni Wulandari- Staff Pengajar

Prodi D3 Kebidanan FIK Unissula Yuli

Fitriasih-Staff Pengajar Prodi D3

Kebidanan Graha Mandiri. 2002;

8. Sumarni, Syarif S. Efektifitas Pemberian

Kombinasi Jus Bayam, Sunkist, Madu

Terhadap Peningkatan Kadar Haemoglobin

Pada Ibu Hamil Anemia Di Puskesmas

Dahlia Kota. J Antara Kebidanan [Internet].

2019;3(1):69-76. Available from:

http://ojs.abdinusantara.ac.id/index.ph

p/antarakebidanan/article/view/140

9. Rahayu R. Efektivitas Penambahan Sari

Kurma Dalam Pemenuhan Gizi Ibu Hamil

Anemia Di Puskesmas Wedi, Kabupaten

Klaten. J Kebidanan dan Kesehat Tradis.

2017;2(2):97-103.

10. Pola H, Orang A, Dengan T, Anak K, 
Tahun U, Raudatul RA, et al. Wiraraja Medika: Jurnal Kesehatan. 2019;9(2):58-62.

11. Jannah M, Puspaningtyas M.

PENINGKATAN KADAR Hb IBU

HAMIL DENGAN JUS KURMA DAN

SARI KACANG HIJAU DI KOTA

PEKALONGAN. PLACENTUM J Ilm

Kesehat dan Apl. 2018;6(2):1.

12. Isnainy UCAS, Arianti L, Rosalia D. Pengaruh Konsumsi Ekstrak Daun Kelor Dan Madu Terhadap Peningkatan Hb Ibu Hamil Di Wilayah Kerja Puskesmas Way Halim Kota Bandar Lampung. Malahayati Nurs J. 2020;2(1):57-67.

13. Kesehatan JS, Banjarmasin PK. Page 97 of 5. 2020;11(2):97-101.

14. Leny. 1035325 Faktor-faktor yang Berhubungan dengan Kejadian Anemia Pada Ibu Hamil. J Kebidanan J Med Sci Ilmu

Kesehat Akad Kebidanan Budi Mulia Palembang. 2019;9(2):161-7.

15. Harnetacia Yessica. Kesehatan Palangka Raya Pelatihan Kesehatan Provinsi Kalimantan Tengah 2 Balai
ABSTRAK. J Skala Kesehat.

2020;11(2).

16. Wardiyah A, Ervina. Pengaruh Pemberian Madu terhadap Kadar Hb pada Ibu Hamil Trimester III di UPTD Puskesmas Peniangan Kecamatan Marga Sekampung Kabupaten Lampung Timur. ManujuMalahayati Nurs J. 2020;2:222-31.

17. Astriana W. Kejadian Anemia pada Ibu Hamil Ditinjau dari Paritas dan Usia. J Aisyah J Ilmu Kesehat. 2017;2(2):123-30.

18. Widowati R, Kundaryanti R, Lestari PP. Pengaruh-Pemberian-Sari- Kurma-Terhadap Ibu Hamil. J Al- Azhar Indones Seri Sains dan Teknol. 2019;5(2):60-5.

19. Fadli F, Fatmawati F. Analisis faktor penyebab kejadian anemia pada ibu hamil. J Kebidanan dan Keperawatan Aisyiyah. 2020;15(2):137-46.

20. Sugita S. Pengaruh Konsumsi Buah Kurma Terhadap Peningkatan Kadar Hemoglobin Pada Ibu Hamil Trimester III. J Kebidanan dan Kesehat Tradis. 2020;5(1):58-66. 